\title{
Lori Vermaas
}

\section{The Conversation I Always Have}

My mother's family has told me

that I remind them of their mother, Maria.

I was too young to know her,

although I witnessed her funeral

in a dusty backroads

cemetery in Mercedes, TX

She seems far, very far away now

but my family tells stories

she once danced with the governor of Nuevo León

and belonged to La Sociedad;

during the violent swirl that was the Revolution

she fled with my family from Cerralvo

and left behind her eldest brother,

as it turned out, forever

it was his choice-they didn't just desert him

my aunt blows the dust off

her mother's old out of tune

Blue Comet mandolin

eight strings

now resting on her living room piano

then my mother remembers Maria's spirited version

of the song, "Mi Capitán,"

which she often played for her husband of thirty plus years, the toughest man my mother says she ever knew,

never mentioning the physical toll

of bearing nine children in America

the years the Valley thinned out her body

costing her a lung

costing her a singing voice 
I wonder what they see in me

when they show me her photographs

I see our resemblance

across the dust and sepia,

and wonder if I'm just mocking myself

with the visual comparison

I mean,

we may be blood,

but these are just images

and old photographs seem empty conversation. 